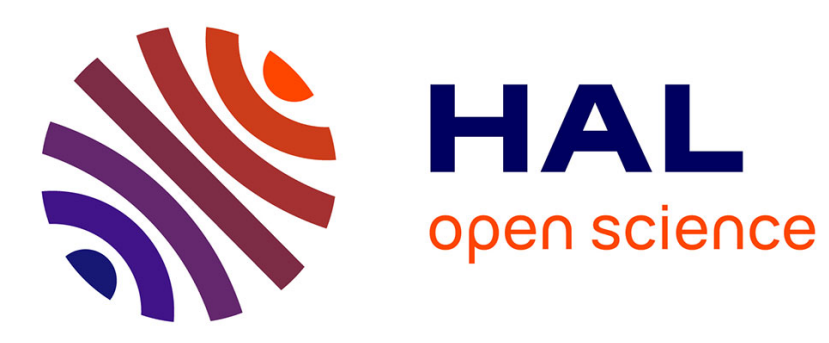

\title{
Early degradation of plant alkanes in soils: a litterbag experiment using C-13-labelled leaves
}

Than Thuy Nguyen Tu, Céline Egasse, Bernhard Zeller, Gérard Bardoux, Philippe Biron, Jean-François Ponge, Brigitte David, Sylvie Derenne

\section{- To cite this version:}

Than Thuy Nguyen Tu, Céline Egasse, Bernhard Zeller, Gérard Bardoux, Philippe Biron, et al.. Early degradation of plant alkanes in soils: a litterbag experiment using C-13-labelled leaves. Soil Biology and Biochemistry, 2011, 43 (11), pp.2222-2228. 10.1016/j.soilbio.2011.07.009 . hal-00625715

\section{HAL Id: hal-00625715 https://hal.science/hal-00625715}

Submitted on 22 Sep 2011

HAL is a multi-disciplinary open access archive for the deposit and dissemination of scientific research documents, whether they are published or not. The documents may come from teaching and research institutions in France or abroad, or from public or private research centers.
L'archive ouverte pluridisciplinaire HAL, est destinée au dépôt et à la diffusion de documents scientifiques de niveau recherche, publiés ou non, émanant des établissements d'enseignement et de recherche français ou étrangers, des laboratoires publics ou privés. 


\section{Early degradation of plant alkanes in soils:}

\section{A litterbag experiment using ${ }^{13} \mathrm{C}$-labelled leaves}

3

4 Thanh Thuy NGUYEN TU*, Céline EGASSE ${ }^{a}$, Bernd ZELLER ${ }^{b}$, Gérard BARDOUX ${ }^{c}$,

5 Philippe BIRON ${ }^{c}$, Jean-François PONGE ${ }^{\mathrm{e}}$, Brigitte $\mathrm{DAVID}^{\mathrm{a}}$, Sylvie DERENNE ${ }^{\mathrm{d}}$

a UMR 7207 MNHN-CNRS-UPMC CR2P, MNHN, Case courrier 48, 57 rue Cuvier, 875231 Paris cedex 05, France

9 b UR 1138 Biogéochimie des Ecosystèmes Forestiers, Centre INRA de Nancy, 54

10280 Champenoux, France

$11{ }^{\mathrm{C}}$ UMR 7618 BioEMCo, Centre INRA de Versailles-Grignon, Bât EGER, 78850

12 Thiverval-Grignon, France

13 d UMR 7618 BioEMCo, UPMC, Case courrier 120, 4 place Jussieu, 75252 Paris

14 Cedex 05, France

15 e UMR 7179 MNHN-CNRS, MNHN, 4 avenue du Petit-Château, 91800 Brunoy,

16 France

17 * corresponding author: ttnguyen@snv.jussieu.fr, Tel: +33(0)140798064, Fax:

$18+33(0) 140793739$

Highlights:

- specific isotope composition of long-chain alkanes was modified during leaf decay

- isotope modification during leaf decay probably reflects a microbial contribution to leaf alkanes

- long-chain alkanes may not be used as an unaltered record of plant isotope composition 


\section{Abstract}

We monitored the carbon isotope composition of bulk leaves and specific longchain alkanes during a four-year litterbag experiment using ${ }^{13} \mathrm{C}$-labelled leaves and unlabelled reference leaves of the European beech tree (Fagus sylvatica L.). Whereas the isotope composition of alkanes from ${ }^{13} \mathrm{C}$-enriched leaves exhibited a marked decrease in ${ }^{13} \mathrm{C}$-content, the isotope composition of unlabelled reference leaves remained nearly constant. We interpreted this difference as evidence for a microbial contribution to the long-chain alkane pool of the decomposing leaves and related it to the progressive invasion of leaves by soil organisms which was revealed upon microscopic examination. These results suggest that long-chain alkanes may not provide an unaltered record of organic carbon isotope composition in soils and sediments.

Keywords: leaf litter decomposition, stable carbon isotopes, lipids, soil organic matter, $\mathrm{n}$-alkanes

\section{Introduction}

The carbon isotope composition of organic matter in soils and sediments has proven useful in documenting past environments, carbon dynamics and the sources of organic matter. However, the isotope composition of bulk organic matter may be altered during decomposition and/or by diagenesis. Indeed, the isotope composition of bulk organic matter corresponds to the weighted mean comprised by the isotope composition of each of its individual constituents. Therefore, the isotope composition of bulk organic matter can be disproportionately altered if the constituents lost by degradation have an isotope composition which differs substantially from that of the preserved constituents (Deines, 1980; Balesdent et al., 1993). Consequently, the isotope analysis of specific compounds having high preservation potential may minimize degradation biases and is becoming increasingly favoured (Wiesenberg et al., 2004; Yamamoto et al., 2010). Among such biomarkers, long-chain fatty lipids such as $n$-alkanes and $n$-acids are the most commonly investigated molecules for specific compound isotope analyses. Indeed, these typical plant components exhibit 
a rather high preservation potential and are relatively easy to analyse. However, these long-chain lipids may not be completely resistant to degradation and their relative distribution may be modified in the early phases of organic matter degradation (Cranwell, 1981; Buggle et al., 2010). Previous investigations on the effects of degradation on the isotope composition of these specific lipids led to contrasting results: either the ${ }^{13} \mathrm{C}$-content of these compounds was unaffected over time or it exhibited a trend towards ${ }^{13} \mathrm{C}$-enrichment of specific molecules (Stahl, 1980; Huang et al., 1997; Mansuy et al., 1997; Mazéas et al., 2002; Nguyen Tu et al., 2004; Chikaraishi and Naraoka, 2006). The observed ${ }^{13} \mathrm{C}$-enrichment of fatty lipids was suggested to have two possible causes: (i) an isotope discrimination effect had occurred during degradation and/or (ii) the fatty lipids were contaminated by longchain lipids derived from microbes. In the absence of categorical evidence, neither of these two alternatives could be favoured or excluded by the previous authors (Nguyen Tu et al., 2004; Chikaraishi and Naraoka, 2006).Nevertheless, the disparity in the reported ${ }^{13} \mathrm{C}$-content trends is likely to be related to differences in the environments investigated: i.e., oxic vs. anoxic, well-drained vs. stagnant water, soil organic matter vs. oil spills, etc. Such a disparity calls for complementary studies in other environments, to better constrain the potential for bias in the isotope record of (paleo)environments.

The present study aimed to determine the precise effects of early degradation on the isotope composition of specific alkanes. A major challenge to investigating the degradation of organic matter is the multiplicity and diversity of its sources. Indeed, it can be difficult to distinguish the actual effects of decomposition from those related to variations in the relative contributions of its sources. An alternative approach is to study materials that are precisely identified, such as the plant leaves that provide the main source of long-chain alkanes in soils and sediments (Eglinton and Hamilton, 1967). Litterbag experiments constitute a prime technique to monitor the fate of leaves through litter decomposition. Indeed, this method allows plant debris to be sampled at specific ages, even at high levels of decomposition (Bocock and Gilbert, 1957; Smith and Bradford, 2003). The present study was thus based on a decay experiment in which beech leaves were enclosed in litterbags. European beech (Fagus sylvatica L.) was chosen as a source because it is a common inhabitant of temperate forests. 
Monitoring the fate of ${ }^{13} \mathrm{C}$-labelled molecules has proven useful to unravel biogeochemical processes in ecological studies (Crossman et al., 2005; Bahri et al., 2008). Therefore, our experiment was carried out using ${ }^{13} \mathrm{C}$-labelled leaves in order to trace the original plant alkanes and to test for possible contamination by microbial alkanes. Stable isotope labelling of plants generally led to ${ }^{13} \mathrm{C}$-enrichment in the order of several hundred-fold per mil (Angers et al., 1997; Zeller et al., 2000; Bahri et al., 2008). However, it may be technically difficult to measure small isotope effects when dealing with such intense labelling. Limited labelling (i.e. lower than 50\%o) provides the opportunity to detect even minor microbial contribution. We thus used slightly ${ }^{13} \mathrm{C}$ enriched beech leaves to monitor the effects of decomposition during a four-year experiment in natural forest soil. To our knowledge, this study represents the first time ${ }^{13} \mathrm{C}$-labelled leaves have been used to investigate, in the field, the effects of degradation on the isotope composition of specific lipids. Our data provide a better understanding of the sources of potential bias related to degradation effects, and hence will allow specific compound isotope analysis in (paleo)environmental studies to be used with greater accuracy and significance.

\section{Material and methods}

\section{1. ${ }^{13} \mathrm{C}$-labelling of beech leaves}

Beech seeds were germinated at the end of May 2004. Young seedlings were transferred at the cotyledon stage to a controlled chamber at the beginning of June 2004. In order to minimize isotope effects linked to soil respiration, plants were grown on vermiculite and fed three times per week with a previously described nutritional solution (Coïc and Lesaint, 1983). The $\mathrm{pCO}_{2}$ and $\delta^{13} \mathrm{C}_{\mathrm{atm}}$ were maintained at 380 ppmv and $+40 \%$, respectively. Climate conditions in the chamber were held constant during the five months of labelling: $70 \%$ relative humidity and $20^{\circ} \mathrm{C}$ day temperature. Four Osram HQI/D Daylight lamps (400 W/D) provided a light intensity of approximately $350 \mu \mathrm{mol} / \mathrm{m}^{2} \cdot \mathrm{s}$ of photosynthetically active radiation during a $15 \mathrm{hr}$ period per day (i.e. 7h-20h). The chamber is described in detail elsewhere (Girardin et al., 2009). Three weeks before the end of the experiment, the conditions were modified in order to induce leaf senescence. The temperature was reduced to $18^{\circ} \mathrm{C}$, 
130 the daylight range was reduced to $8 \mathrm{hr}(9 \mathrm{~h}-17 \mathrm{~h})$ and nutritional solution was provided

131 only once per week. The leaves thus obtained exhibited a mean $\delta^{13} \mathrm{C}$ value of

$132+25.0 \%$ and ranged between $+16.3 \%$ and $+35.3 \%$.

\subsection{Degradation experiment}

\subsubsection{Experimental site}

The degradation experiment was established in the "Breuil-Chenue" experimental forest site located in Burgundy, France $\left(47^{\circ} 18^{\prime} 10^{\prime \prime} \mathrm{N}, 4^{\circ} 4^{\prime} 44^{\prime \prime} \mathrm{E}\right)$. This forest is part of the "Parc Naturel Régional du Morvan", a protected area where urban pollution is minimal. The field is situated on a shelf at $650 \mathrm{~m}$ above sea level and exhibits a slight northwest-facing slope. Mean annual temperature and precipitation at the site are $9^{\circ} \mathrm{C}$ and $1,280 \mathrm{~mm}$, respectively. The bedrock is the alkaline granite of "La Pierre qui Vire" covered by a thin layer of eolian silt. Soils are classified as dystric cambisol (WRB, 2006) with a thick moder on top $(\sim 10 \mathrm{~cm})$. They are acidic soils with $\mathrm{pH}$ values of 4-4.5 and have a poorly saturated cation exchange complex. More information on the experimental site is available elsewhere (Moukoumi et al., 2006; Andrianarisoa et al., 2010). The incubation took place in a stand planted with 30 year-old European beech trees (Fagus sylvatica $L$ ). Unlabelled senescent leaves were also incubated as reference material. They were harvested in October 2004, in the stand where the incubation took place. The leaves were collected at the same height $(\sim 1.5 \mathrm{~m})$ from the branches of several different trees in order to obtain mean composition and to minimize biases linked to intrapopulational variability.

\subsubsection{Selection of senescent leaves}

After harvesting, leaves were rinsed with distilled water to remove extraneous particles and dried at $45^{\circ} \mathrm{C}$ until they attained a constant weight. Leaves were then examined under a dissecting microscope to monitor morphological changes. One milligram was removed from each leaf for elemental and isotope analyses (see section 2.3.1) to determine the main biochemical characteristics of the leaves at the initial stage of degradation. Each batch was composed of 10-15 leaves and corresponded to approximately one gram of organic matter. Batches were assembled using leaves from as many different trees/plants as possible to obtain equivalent batches. ${ }^{13} \mathrm{C}$-enriched leaves were selected to constitute batches having isotope 
164 variabilities similar to those of natural leaves (i.e. a standard deviation $\leq 0.8 \%$ ). The mean isotope composition of the batches of labelled leaves varied within a rather large range (i.e. $+16.3 \%$ o to $+36.8 \%$ ) that precluded direct comparison between batches. Moreover, labelled and unlabelled leaves were grown in different conditions and exhibited slightly different biochemical characteristics. Therefore, to avoid biases linked to differences between the ${ }^{13} \mathrm{C}$-enriched leaf batches and the wild leaf batches at the initial stage, the following discussion will be based primarily on the comparison of degradation trends (i.e. $\Delta^{13} \mathrm{C}_{\text {degradation }}=\delta^{13} \mathrm{C}_{\text {degraded }}-\delta^{13} \mathrm{C}_{\text {initial }}$ ).

\subsubsection{Litterbag incubation}

Preliminary investigations showed that in contrast to aluminium nets, the nylon and polypropylene nets generally used for litterbags may release substantial amounts of contaminants that could be potentially extracted with the leaf lipids. Accordingly, the litterbags $(9.5 \times 14.5 \mathrm{~cm})$ were made of aluminium wire. The mesh size was $1.4 \times 1.8 \mathrm{~mm}$ and was small enough to contain small leaf litter debris yet large enough to permit aerobic microbial activity and free entry of small soil animals. Indeed, soil fauna at the experimental site was dominated in biomass by enchytraeids, and contained to a lesser extent, mites and springtails, as it is generally the case in moders (Swift et al., 1979; Ponge et al., 1997). Before being enclosed in litterbags, the leaves were weighed and then re-moistened with distilled water to recreate the natural moisture conditions of leaf fall in autumn. The litterbags were placed in the field at the end of autumn 2004, on the surface of the existing forest litter layer, akin to leaves falling naturally in autumn. Samples were retrieved from the field at 5, 10, 15, 20, 30, 40, 52, 79, 129 and 207 weeks (four years). At each sampling date, two bags of natural leaves and two bags of labelled leaves were taken.

\subsection{Analyses}

The recovered material was first rinsed with distilled water to remove obvious extraneous particles such as mosses, roots or arthropods. Leaves were then scanned, dried to constant weight at $45^{\circ} \mathrm{C}$, weighed and examined under a dissecting microscope. Samples were stored dark in aluminium foil at $5^{\circ} \mathrm{C}$ until analysis. All the 
197 leaves of each litterbag were then combined and ground fine enough to pass through a $500 \mu \mathrm{m}$ mesh. An aliquot of the so-obtained powder ( 1 mg) was taken for bulk elemental and isotope characterization (see 3.2.1.) and the rest was submitted to the extraction procedure.

\subsubsection{Isotope and elemental analyses of bulk leaves}

Stable isotope ratios were measured using an automated unit that combines an elemental analyser with an isotope ratio mass spectrometer. The samples were combusted in a Carlo-Erba CHN elemental analyser connected to a VG-SIRA 10, isotope ratio mass spectrometer. After flash combustion with copper oxide at $1000^{\circ} \mathrm{C}$, $\mathrm{CO}_{2}$ was cryogenically distilled, purified and introduced on-line into the mass spectrometer to determine carbon isotope ratios (Girardin and Mariotti, 1991). The $\delta^{13} \mathrm{C}$ values were measured with a precision of $0.1 \%$ o $(1 \sigma)$.

\subsubsection{Lipid extraction and alkane fractionation}

Leaf powder was ultrasonically extracted for $20 \mathrm{~min}$ with $30 \mathrm{ml}$ dichloromethane/methanol $(2 / 1 ; \mathrm{v} / \mathrm{v})$. The mixture was centrifuged (10 $\min$ at 4,000 rpm) and the extracted lipids were recovered in the supernatant. The extraction procedure was repeated six times with the centrifugation residue (pellet). The combined extracts were concentrated by rotary evaporation and then dried under nitrogen gas. The extract yield was determined by weighing the dried combined extracts. The total extract was then fractionated on an alumina column $(1 \mathrm{~g}$ alumina per 10 mg dry extract, Sigma-Aldrich 507C 150 mesh) deactivated to Brockmann grade IV by adding $0.1 \%$ by weight of distilled water. Alkanes were recovered in the apolar fraction after elution with heptane ( $4 \mathrm{ml}$ for $1 \mathrm{~g}$ of alumina). A known amount of an internal standard (i.e. tetratriacontane) was introduced in the fraction for quantification purposes.

\subsubsection{Alkane-specific isotope analyses}

Alkanes were identified by gas chromatography using a an Agilent 6890N gas chromatograph (GC) equipped with a split/splitless injector and fitted with a fused silica capillary column, coated with VF5-MS (50 m × $0.32 \mathrm{~mm}$ i.d., $0.12 \mu \mathrm{m}$ film 
230 then increased to $325^{\circ} \mathrm{C}$ at $4^{\circ} \mathrm{C} / \mathrm{min}$, then held at $325^{\circ} \mathrm{C}$ for $30 \mathrm{~min}$. Helium was used

231 as carrier gas at a constant flow of $2 \mathrm{ml} / \mathrm{min}$. The splitless injector and flame

232 ionization detector temperatures were held at $350^{\circ} \mathrm{C}$. Compound-specific $\delta^{13} \mathrm{C}$ values

233 of the dominant alkanes were determined with a Micromass IsoChrom III coupling,

234 comprised by an IsoChrom isotope ratio mass spectrometer coupled to a GC via a

235 Micromass combustion interface ( $\mathrm{CuO}$ combustion furnace at $850^{\circ} \mathrm{C}$ and cryogenic

236 trap at $\left.-100^{\circ} \mathrm{C}\right) \cdot \delta^{13} \mathrm{C}$ values were measured with a precision $(1 \sigma)$ of $0.5 \%$. Each

237 sample was run in triplicate. To enable comparison between leaves that exhibited a

238 rather large range of isotope variability, the isotope compositions of specific alkanes

239 were expressed relative to the bulk isotope composition of undegraded leaves

240 according to: $\Gamma^{13} \mathrm{C}_{\text {alkane }}=\delta^{13} \mathrm{C}_{\text {alkane }}-\delta^{13} \mathrm{C}_{\text {undegraded leaves }}$.

\section{Results and discussion}

\subsection{Bulk degradation patterns}

Microscopic examination of the leaves revealed traces of epiphytic microflora beginning at the initial/senescent stage. Indeed, fungal fructifications (Fig. 1a) and mycelia (Fig. 1b) were detected on several leaves. During the experiment, the leaves exhibited progressive degradation patterns. The first evidence of grazing by soil fauna, in which the lower cuticle was missing between the tertiary/quaternary veins, was detected after five weeks of decomposition in the field. The lower cuticle of

253 leaves degrades more easily than the upper cuticle and the veins are much thicker and decay more slowly. These grazing patterns are typical of litter-consuming fauna, notably the enchytraeids that are very abundant in moders (Ponge, 1999). These grazing marks became frequently observed after 10 weeks of decomposition (Fig. 1c). After one year, the upper cuticle of leaves showed evidence of grazing, leading to complete holes between veins (Figs. 1d and 1e) and to a progressive skeletonization of the leaves (Fig. 1f). After decomposing for four years, the only

260 original material remaining consisted of bundles of skeletonized leaf fragments (Fig.

261 1f). Exogenous material also accumulated on the leaves during the experiment.

262 Fungi progressively invaded the leaf surfaces (Fig. 1d); on leaves exposed to light, 
micro-algae colonized the gaps left by grazing fauna (Fig. 1d); faecal material was deposited by soil fauna (Fig. 1e); and conifer pollen grains probably originating from adjacent stands were also deposited (Fig. 1e and 1f). Labelled and unlabelled leaves exhibited similar degradation patterns upon microscopic examination.

After four years of decomposition in the field, the litter leaves had lost $50-90 \%$ of their initial dry weight (Fig. 2a). A rather large weight loss was observed during the first several days followed by slower decomposition rates afterwards. This decomposition trend is in agreement with other studies that reported the decomposition patterns of beech litters under similar conditions (Cortez, 1998; Ono et al., 2009). ${ }^{13} \mathrm{C}$-labelled leaves appeared to degrade slightly more quickly than natural leaves during the first three years (Fig. 2a). Nevertheless, both leaf types eventually lost equivalent weights after four years (Fig. 2a). The difference in initial decomposition rates of the natural and the labelled leaves probably reflected differences in initial leaf quality. Among other factors, the $\mathrm{C} / \mathrm{N}$ ratio was lower in labelled leaves than in natural leaves at the initial stage (with means of 19.6 and 26.9 for labelled and unlabelled leaves, respectively). This lower $\mathrm{C} / \mathrm{N}$ ratio probably contributed significantly to the difference in decomposition rate, and has been suggested previously (Melin, 1930; Witkamp, 1966; Taylor et al., 1989). Litter quality differences may be attributed to growing conditions that were probably more favourable in the labelling chamber than in the field. To avoid potential bias linked to this difference in litter quality, we based our discussion on degradation trends calculated relative to the initial/undegraded stage of each batch, rather than on direct comparisons between the two crude datasets. Regardless of the dataset, no specific trends were evident with respect to the carbon content or the $\mathrm{C} / \mathrm{N}$ ratio, both of which remained relatively constant during the experiment $(\sim 450 \mathrm{mg} / \mathrm{g}$ and $\sim 20$, respectively; data not shown). These values agree with those previously reported for beech leaves and litter found at the experimental site (Zeller et al., 2007).

Lipids of senescent leaves (i.e. at the initial stage of degradation) accounted for $\sim 11 \mathrm{wt} . \%$ and $\sim 16 \mathrm{wt} . \%$ of the dry material for unlabelled and ${ }^{13} \mathrm{C}$-labelled leaves, respectively. Here again, the higher lipid content of the labelled leaves compared to that of the natural leaves was probably due to differences in growing conditions. Nevertheless, both leaf types exhibited similar degradation patterns for lipids (Fig. $2 b)$. Lipid content decreased sharply during the first month of the experiment, reaching $\sim 6$ wt.\% of dry material. Leaf lipid content then progressively decreased to 
become $>1$ wt.\% after four years of degradation (Fig. 2b). Final lipid loss was greater

298 than 99 wt.\% of the initial lipid content, which was much higher than the bulk weight loss (i.e. 80 wt.\% of initial leaves). Accordingly, lipids were degraded to a greater extent than were the non-lipidic constituents of the leaves. The chemical composition of lipids from senescent beech leaves has been reported previously (Nguyen Tu et al., 2007): most $n$-alkanes consisted of between 16 and 29 carbon atoms and were markedly dominated by the $\mathrm{C}_{27}$ homologue. The initial alkane content present in senescent leaves decreased substantially during the four year decomposition, as illustrated by the amount of the $\mathrm{C}_{27}$ homologue (Fig. 2c).

\subsection{Isotope degradation patterns}

The bulk isotope composition of unlabelled leaves remained nearly constant during decomposition, whereas that of the ${ }^{13} \mathrm{C}$-labelled leaves exhibited a significant decrease over time (i.e. ${ }^{13} \mathrm{C}$-depletion, Fig. 3a). This ${ }^{13} \mathrm{C}$-depletion reached $12 \%$ after the four-year decomposition period. In agreement with previous reports (Collister et al., 1994; Chikaraishi et al., 2004), specific alkanes appeared to be ${ }^{13} \mathrm{C}$-depleted compared to the bulk leaves. The ${ }^{13} \mathrm{C}$-content of specific alkanes exhibited degradation patterns similar to that of bulk leaves. For example, the ${ }^{13} \mathrm{C}$-content of the $\mathrm{C}_{27}$ homologue (Fig. $3 \mathrm{~b}$ ) remained nearly constant in the unlabelled leaves but exhibited a decrease $\sim 20 \%$ in the ${ }^{13} \mathrm{C}$-enriched leaves. The $\mathrm{C}_{25}$ and $\mathrm{C}_{29}$ homologues exhibited degradation patterns similar to that of $\mathrm{C}_{27}$ (data not shown). At the bulk leaf scale, as well as at the molecular scale, previous authors observed either increasing $\delta^{13} \mathrm{C}$ values or unchanging isotope content during organic matter degradation

321 (Balesdent et al., 1993; Connin et al., 2001). These studies dealt with unlabelled material and reported ${ }^{13} \mathrm{C}$-enrichments of up to $6 \%$. ${ }^{13} \mathrm{C}$-depletion in the context of unlabelled organic matter decomposition was reported in only one early study of bulk Spartina rhizomes decaying in salt marsh sediments (Benner et al., 1987). The observed variability in the trends of ${ }^{13} \mathrm{C}$ content that has been documented in the literature is likely due to the wide range of environments employed to investigate decomposition. In a recent experiment dealing with highly ${ }^{13} \mathrm{C}$-enriched (i.e. $\delta^{13} \mathrm{C} \approx$ $166 \%$ ) poplar leaves, Rubino and colleagues (2010) reported a decrease of $41 \%$ in $\delta^{13} \mathrm{C}$ after one year of litter degradation. 
Disproportionate changes in isotope content during degradation may reflect either contributions from exogenous material having different isotope compositions or an "isotope effect" (Natelhoffer and Fry, 1988; Balesdent et al., 1993). The latter phenomenon describes the selective degradation of chemical compounds having $\delta^{13} \mathrm{C}$ values deviating from that of bulk leaves and/or kinetic discrimination during metabolism of leaf constituents by degrading microorganisms (i.e. preferential metabolism of the material that is ${ }^{13} \mathrm{C}$-depleted). Kinetic discrimination would be expected to generate similar patterns for a given species in a given environment. This explanation can thus be ruled out in our experiment since ${ }^{13} \mathrm{C}$-labelled and unlabelled leaves exhibited different isotope depletion patterns. The preferential degradation of the lipids noted in section 3.1 did not likely account for the observed isotope trends because lipids corresponded to only between 1 and $15 \%$ of the bulk leaf weight. Moreover, lipids are ${ }^{13} \mathrm{C}$-depleted compared to the bulk leaves (Park and Epstein, 1960; Monson and Hayes, 1982). Selective degradation of ${ }^{13} \mathrm{C}$-enriched molecules such as carbohydrates may partly explain the isotope content trends detected in bulk leaves. Indeed, ${ }^{13} \mathrm{C}$-labelled leaves were grown in optimal conditions which may have led to them having higher carbohydrate content than the unlabelled leaves. Since carbohydrates can be ${ }^{13} \mathrm{C}$-enriched up to $5 \%$ with respect to bulk leaves (Ehleringer, 1991), this may have played a role in the different behaviours of the isotope content in labelled and unlabelled leaves. Nevertheless, the depletion observed here for bulk labelled leaves reached $12 \%$ after four years of degradation. A complementary explanation is thus necessary to fully explain the observed isotope patterns, especially with respect to those observed for specific alkanes. Accordingly, this is most likely due to a contribution from exogenous organic matter that is of a $\delta^{13} \mathrm{C}$ value lower than that of the labelled leaves. Such an exogenous contribution may be linked to the progressive invasion and/or accumulation of algae, faeces and fungi which were revealed upon microscopic examination. Although such soil-derived microbial biomass is generally considered to be devoid of long chain lipids such as $n$ alkanes, microbes such as fungi or algae may contain long-chain lipids (Jones and Young, 1970; Rezanka and Sokolov, 1993; Volkman et al., 1998).

The isotope composition of the exogenous organic matter that may have contributed to the decaying leaves is likely similar to or slightly enriched in ${ }^{13} \mathrm{C}$ with respect to the original unlabelled material, whether at the bulk leaf level or the molecular level. Indeed, soil microbial biomass is generally considered to be ${ }^{13} \mathrm{C}$ - 
enriched by 1-3\%o compared to soil organic matter (Werth and Kuzyakov, 2010; and reference therein). Fungi can be either slightly ${ }^{13} \mathrm{C}$-depleted or ${ }^{13} \mathrm{C}$-enriched relative to the ${ }^{13} \mathrm{C}$ content of the substrate, depending on the fungus taxon and on the substrate (Gleixner et al., 1993; Hobbie et al., 2001; Abraham and Hesse, 2003; Ruess et al., 2005; Cowie et al., 2009). The sporophores of the saprophytic fungi from our experimental site were shown to be ${ }^{13} \mathrm{C}$-enriched by $\sim 4 \%$ with respect to their substrate (Zeller et al., 2007). Specific lipids from heterotrophic microorganisms have been shown to be either ${ }^{13} \mathrm{C}$-enriched or ${ }^{13} \mathrm{C}$-depleted by a few per mill, with respect to their total biomass, according to the taxon and to the environment (Teece et al., 1999; Abraham and Hesse, 2003; Cowie et al., 2009). The carbon isotope composition of faeces relative to diet is poorly known for soil fauna and seems to vary among taxa for small metazoans (DeNiro and Epstein, 1978; Tamelander et al., 2006). Specific compounds of faeces from soil fauna may reflect that of their diet as shown for copepod sterols (Grice et al., 1998). Therefore, the exogenous contribution to the original plant material probably had an isotope composition similar to or slightly higher than that of the unlabelled leaves. This implies that fungi, other microbes and the animals that produced the faeces in the litter likely derived mostly their diet from unlabelled organic matter that was the main substrate in the experimental site.

By comparing degradation patterns in ${ }^{13} \mathrm{C}$-labelled and unlabelled leaves, this study provides evidence for microbial contributions to decaying litter at the level of bulk organic material and at the level of specific alkanes. This exogenous contribution was probably substantive but relatively small when compared to the bulk mass of the leaves in our samples. In this way, no isotope trend would be expected for unlabelled leaves while ${ }^{13} \mathrm{C}$-enriched leaves would be expected to exhibit decreasing $\delta^{13} \mathrm{C}$ values throughout the decay period. While contribution from microbial organic matter to bulk plant organic matter has been well established previously, this has not been reported for long-chain alkanes. These molecules have been generally considered to be typical of plants, although recent studies suggested that microbial alkanes may contribute to degrading plant alkanes in soils and sediments (Buggle et al., 2010). The present study thus provides direct isotope arguments in favour of microbial contribution rather than isotope discrimination effects to explain the ${ }^{13} \mathrm{C}$-enrichment trends previously reported for plant alkanes in soils (Nguyen Tu et al., 2004; Chikaraishi and Naraoka, 2006). Although microbial contribution appeared to be relatively limited for unlabelled/natural litter for this four- 
year-incubation, results from other studies suggest that it may lead to a ${ }^{13} \mathrm{C}$ enrichment of up to 4\%o (Chikaraishi and Naraoka, 2006). This result was actually based on lipids extracted from bulk soils sampled from the horizon underlying the litter layer (i.e. 2-10 cm in depth). Therefore, it may be suggested that the high ${ }^{13} \mathrm{C}$ enrichment detected by Chikaraishi and Naraoka (2006) corresponded to the accumulation over time of an increase in ${ }^{13} \mathrm{C}$-content that was negligible at first but that led to a measurable effect in the long-term. Chikaraishi and Naraoka (2006) found that long-chain $n$-alkanols and $n$-alkanoic acids can also undergo significant ${ }^{13} \mathrm{C}$-enrichment during leaf degradation in soils. We may therefore generalize our findings to other long-chain fatty lipids, which may also be contaminated by microbial lipids. Thus, circumspection is called for when considering long-chain fatty lipids as unaltered record of organic carbon isotope composition.

\section{Acknowledgements}

We are indebted to Thierry Bariac for access to the controlled chamber and to Patricia Richard for technical support during the labelling experiment. Thanks are also due to Jacques Ranger for access to the experimental site of Breuil-Chenue forest and Dominique Gelhaye and Jean-Pierre Calmet for their assistance in the field. We are grateful to Christelle Anquetil, Nicolas Péchot and Valérie Pouteau for mass spectrometry facilities as well as Stéphane Lemettre and Florent Zanetti for help in lipid preparation. We also thank Jorge Cubo, Yongsong Huang and Gladys Loranger for helpful discussions along with Stéphane Peigné and Son Nguyen Tu for technical assistance. Thanks are due to the two anonymous referees who provided constructive reviews and to Kurt Liittschwager for correction of the English of the manuscript. This work was funded by a grant from Fond National pour la Science 


\section{References}

Abraham, W.-R., Hesse, C., 2003. Isotope fractionations in the biosynthesis of cell components by different fungi: a basis for environmental carbon flux studies. FEMS Microbiology Ecology 46, 121-128.

Andrianarisoa, K., Zeller, B., Poly, F., Siegenfuhr, H., Bienaimé, S., Ranger, J., Dambrine, E., 2010. Control of Nitrification by Tree Species in a CommonGarden Experiment. Ecosystems 13, 1171-1187.

Angers, D.A., Recous, S., Aita, C., 1997. Fate of carbon and nitrogen in water-stable aggregates during decomposition of ${ }^{13} \mathrm{C}^{15} \mathrm{~N}$-labelled wheat straw in situ. European Journal of Soil Science 48, 295-300.

Bahri, H., Rasse, D.P., Rumpel, C., Dignac, M.-F., Bardoux, G., Mariotti, A., 2008. Lignin degradation during a laboratory incubation followed by ${ }^{13} \mathrm{C}$ isotope analysis. Soil Biology and Biochemistry 40, 1916-1922.

Balesdent, J., Girardin, C., Mariotti, A., 1993. Site related $\delta^{13} \mathrm{C}$ of tree leaves and soil organic matter in a temperate forest. Ecology 74, 1713-1721.

Benner, R., Fogel, M.L., Sprague, E.K., Hodson, R.E., 1987. Depletion of ${ }^{13} \mathrm{C}$ in lignin and its implicatons for stable carbon isotope studies. Nature 329, 708-710.

Bocock, K.L., Gilbert, O.J.W., 1957. The disappearance of leaf litter under different woodland conditions. Plant and Soil 9, 179-185.

Buggle, B., Wiesenberg, G.L.B., Glaser, B., 2010. Is there a possibility to correct fossil n-alkane data for postsedimentary alteration effects? Applied Geochemistry 25, 947-957.

Chikaraishi, Y., Naraoka, H., 2006. Carbon and hydrogen isotope variation of plant biomarkers in a plant-soil system. Chemical Geology 231, 190-202.

Chikaraishi, Y., Naraoka, H., Poulson, S.R., 2004 Carbon and hydrogen isotopic fractionation during lipid biosynthesis in a higher plant (Cryptomeria japonica). Phytochemistry 65, 323-330.

Coïc, Y., Lesaint, C., 1983. Cultures hydroponiques, Flammarion, Paris.

Collister, J.W., Rieley, G., Eglinton, G., Fry, B., 1994. Compound-specific $\delta^{13} \mathrm{C}$ analyses of leaf lipids from plants with differing carbon dioxide metabolisms. Organic Geochemistry 21, 619-627. 
Connin, S.L., Feng, X., Virginia, R.A., 2001. Isotopic discrimination during long-term decomposition in an arid land ecosystem. Soil Biology and Biochemistry 33, 41-51.

Cortez, J., 1998. Field decomposition of leaf litters: relationships between decomposition rates and soil moisture, soil temperature and earthworm activity. Soil Biology and Biochemistry, 30, 783-793.

Cowie, B.R., Slater, G.F., Bernier, L., Warren, L.A., 2009. Carbon isotope fractionation in phospholipid fatty acid biomarkers of bacteria and fungi native to an acid mine drainage lake. Organic Geochemistry 40, 956-962.

Cranwell, P.A., 1981. Diagenesis of free and bound lipids in terrestrial detritus deposited in a lacustrine sediment. Organic Geochemistry 3, 79-89.

Crossman, Z.M., Ineson, P., Evershed, R.P., 2005. The use of ${ }^{13} \mathrm{C}$ labelling of bacterial lipids in the characterisation of ambient methane-oxidising bacteria in soils. Organic Geochemistry 36, 769-778.

Deines, P., 1980. The isotopic composition of reduced organic carbon, in: Fritz, P., Fontes, J.C., (Eds.), Handbook of Environmental Isotope Geochemistry, 1. Elsevier, London, pp. 329-406.

DeNiro, M.J., Epstein, S., 1978. Influence of diet on the distribution of carbon isotopes in animals. Geochimica et Cosmochimica Acta 42, 495-506.

Eglinton, G., Hamilton, R.J., (1967) Leaf epicuticular waxes. Science, 156, 13221335.

Ehleringer, J.R., $1991 .{ }^{13} \mathrm{C} /{ }^{12} \mathrm{C}$ fractionation and its utility in terrestrial plant studies, in: Coleman, D.C., Fry, B. (Eds.), Carbon Isotope Techniques. Academic Press, San Diego, pp. 187-201.

Girardin, C., Mariotti, A., 1991. Analyse isotopique $d u{ }^{13} \mathrm{C}$ en abondance naturelle dans le carbone organique : un système automatique avec robot préparateur. Cahiers Orstom - Série Pédologie 26, 371-380.

Girardin, C., Rasse, D.P., Biron, P., Ghashghaie, J., Chenu, C., 2009. A method for ${ }^{13} \mathrm{C}$-labeling of metabolic carbohydrates within French bean leaves (Phaseolus vulgaris L.) for decomposition studies in soils. Rapid Communications in Mass Spectrometry 23, 1792-1800.

Gleixner, G., Danier, H.J., Werner, R.A., Schnmidt, H.L., 1993. Correlation between the ${ }^{13} \mathrm{C}$ content of primary and secondary products in different cell 

compartments and that in decomposing basidiomycetes. Plant Physiology 102, 1287-1290.

Grice, K., Klein Breteler, W.C.M., Schouten, S., Grossi, V., de Leeuw, J.W., Sinninghe Damsté, J.S., 1998. Effects of zooplankton herbivory on biomarker proxy records. Paleoceanography 13, 686-693.

Hobbie, E.A., Weber, N.S., Trappe, J.M., 2001. Mycorrhizal vs Saprotrophic Status of Fungi: The Isotopic Evidence. New Phytologist 150, 601-610.

Huang, Y., Eglinton, G., Ineson, P., Latter, P.M., Bol, R., Harkness, D.D., 1997. Absence of carbon isotope fractionation of individual n-alkanes in a 23-year field decomposition experiment with Calluna vulgaris. Organic Geochemistry 26, 497-501.

Jones, J.G., Young, B.V., 1970. Major paraffin constituents of microbial cells with particular references to Chromatium sp. Archives of Microbiology 70, 82-88.

Mansuy, L., Philp, R.P., Allen, J., 1997. Source identification of oil spills based on the isotopic composition of individual components in weathered oil samples. Environmental Science and Technology 31, 3417-3425.

Mazéas, L., Budzinski, H., Raymond, N., 2002. Absence of stable carbon isotope fractionation of saturated and polycyclic aromatic hydrocarbons during aerobic bacterial biodegradation. Organic Geochemistry 33, 1259-1272.

Melin, E., 1930. Biological Decomposition of Some Types of Litter From North American Forests. Ecology, 11, 72-101.

Monson, K.D., Hayes, J.M., 1982. Carbon isotopic fractionation in the biosynthesis of bacterial fatty acids. Ozonolysis of unsaturated fatty acids as a means of determining the intramolecular distribution of carbon isotopes. Geochimica et Cosmochimica Acta 46, 139-149.

Moukoumi, J., Munier-Lamy, C., Berthelin, J., Ranger, J., 2006. Effect of tree species substitution on organic matter biodegradability and mineral nutrient availability in a temperate topsoil. Annals of Forest Science 63, 763-771.

Natelhoffer, K.J., Fry, B., 1988. Controls on natural nitrogen-15 and carbon-13 abundances in forest soil organic matter. Soil Science Society of America Journal 52, 1633-1640.

Nguyen Tu, T.T., Derenne, S., Largeau, C., Bardoux, G., Mariotti, A., 2004. Diagenesis effects on specific carbon isotope composition of plant $n$-alkanes. Organic Geochemistry, 35, 317-329. 
Nguyen Tu, T.T., Egasse, C., Zeller, B., Derenne, S., 2007. Chemotaxonomical investigations of fossil and extant beeches. I. Leaf lipids from the extant Fagus sylvatica L. Comptes Rendus Palevol 6, 451-461.

Ono, K., Hirai, K., Morita, S., Ohse, K., Hiradate, S., 2009. Organic carbon accumulation processes on a forest floor during an early humification stage in a temperate deciduous forest in Japan: Evaluations of chemical compositional changes by ${ }^{13} \mathrm{C}$ NMR and their decomposition rates from litterbag experiment. Geoderma 151, 351-356.

Park, R., Epstein, S., 1960. Carbon isotope fractionation during photosynthesis. Geochimica et Cosmochimica Acta 21, 110-126.

Ponge, J.-F., 1999. Horizons and Humus Forms in Beech Forests of the Belgian Ardennes. Soil Science Society of America Journal 63, 1888-1901.

Ponge, J.F., Arpin, P., Sondag, F., Delecour, F., 1997. Soil fauna and site assessment in beech stands of the Belgian Ardennes. Canadian Journal of Forest Research 27, 2053-2064.

Rezanka, T., Sokolov, M.Y., 1993. Rapid method for the enrichment of very longchain fatty acids from microorganisms. Journal of Chromatography A 636, 249-254.

Rubino, M., Dungait, J.A.J., Evershed, R.P., Bertolini, T., De Angelis, P., D'Onofrio, A., Lagomarsino, A., Lubritto, C., Merola, A., Terrasi, F., Cotrufo, M.F., 2010. Carbon input belowground is the major $C$ flux contributing to leaf litter mass loss: Evidences from a ${ }^{13} \mathrm{C}$ labelled-leaf litter experiment. Soil Biology and Biochemistry 42, 1009-1016.

Ruess, L., Tiunov, A., Haubert, D., Richnow, H.H., Häggblom, M.M., Scheu, S., 2005. Carbon stable isotope fractionation and trophic transfert of fatty acids in fungal based soil food chains. Soil Biology and Biochemistry, 37, 945-953.

Smith, V.C., Bradford, M.A., 2003. Litter quality impacts on grassland litter decomposition are differently dependent on soil fauna across time. Applied Soil Ecology 24, 197-203.

Stahl, W.J., (1980) Compositional changes and ${ }^{13} \mathrm{C} /{ }^{12} \mathrm{C}$ fractionation during the degradation of hydrocarbons by bacteria. Geochimica et Cosmochimica Acta 44, 1903-1907.

Swift, M.J., Heal, O.W., Anderson, J.M., 1979. Decomposition in terrestrial ecosystems. University of California Press, Berkeley. 
Tamelander, T., Søreide, J.E., Hop, H., Carroll, M.L., 2006. Fractionation of stable isotopes in the Arctic marine copepod Calanus glacialis: Effects on the isotopic composition of marine particulate organic matter. Journal of Experimental Marine Biology and Ecology 333, 231-240.

Taylor, B.R., Parkinson, D., Parsons, W.F.J., 1989. Nitrogen and Lignin Content as Predictors of Litter Decay Rates: A Microcosm Test. Ecology 70, 97-104.

Teece, M.A., Fogel, M.L., Dollhopf, M.E., Nealson, K.H., 1999. Isotopic fractionation associated with biosynthesis of fatty acids by a marine bacterium under oxic and anoxic conditions. Organic Geochemistry 30, 1571-1579.

Volkman, J.K., Barrett, S.M., Blackburn, S.J., Mansour, M.P., Sikes, E.L., Gelin, F., 1998. Microalgal biomarkers: A review of recent research development. Organic Geochemistry 29, 1163-1179.

Werth, M., Kuzyakov, Y., 2010. ${ }^{13} \mathrm{C}$ fractionation at the root-microorganisms-soil interface: A review and outlook for partitioning studies. Soil Biology and Biochemistry 42, 1372-1384.

Wiesenberg, G.L.B., Schwarzbauer, J., Schmidt, M.W.I., Schwark, L., 2004. Source and turnover of organic matter in agricultural soils derived from $n$-alkane/ncarboxylic acid compositions and C-isotope signatures. Organic Geochemistry 35, 1371-1393.

Witkamp, M., 1966. Decomposition of Leaf Litter in Relation to Environment, Microflora, and Microbial Respiration. Ecology 47, 194-201.

Yamamoto, S., Kawamura, K., Seki, O., Meyers, P.A., Zheng, Y., Zhou, W., (2010) Paleoenvironmental significance of compound-specific $\delta 13 \mathrm{C}$ variations in $n$ alkanes in the Hongyuan peat sequence from southwest China over the last 13 ka. Organic Geochemistry 41, 491-497.

Zeller, B., Brechet, C., Maurice, J.-P., Le Tacon, F., 2007. ${ }^{13} \mathrm{C}$ and ${ }^{15} \mathrm{~N}$ isotopic fractionation in trees, soils and fungi in a natural forest stand and a Norway spruce plantation. Annals of Forest Science 64, 419-429.

Zeller, B., Colin-Belgrand, M., Dambrine, E., Martin, F., Bottner, P., 2000.

Decomposition of ${ }^{15} \mathrm{~N}$-labelled beech litter and fate of nitrogen derived from litter in a beech forest. Oecologia 123, 550-559.

WRB, 2006. IUSS Working group. World reference base for soil resources 2006, sedond ed. World Soil Ressources Reports N¹3. FAO, Rome. 


\section{Figure captions}

\section{Figure 1.}

599 Typical beech leaf decomposition patterns observed under dissecting microscope.

600 Epiphytic fungi on senescent leaves: fructifications (a.) and mycelia (b.). Marks of 601 grazing by soil fauna after 1.5 years of decomposition (c.). Decomposition patterns 602 after 2.5 years of decay: skeletonization of leaves (d. arrow $\mathrm{H}$ and $\mathbf{f}$.), increasing 603 invasion by fungi (d.) and algae (d. arrow A), faecal material (e. arrow F) and conifer 604 pollen grains (e. arrows $P$ and f. arrows)

605

606 Figure 2.

607 Changes in geochemical parameters measured for bulk beech leaves.

608 Solid symbols: unlabelled leaves, open symbols: ${ }^{13} \mathrm{C}$-labelled leaves. a. Bulk weight 609 (percentage of initial weight). b. Lipid content (percentage of initial leaf weight). c.

610 Heptacosane content (with respect to initial leaf weight).

\section{Figure 3.}

614 Changes in isotope composition.

615 Solid symbols: unlabelled leaves; open symbols: ${ }^{13} \mathrm{C}$-labelled leaves. a. ${ }^{13} \mathrm{C}$-content 616 of bulk leaves $\left(\Delta^{13} \mathrm{C}=\delta^{13} \mathrm{C}_{\text {degraded }}-\delta^{13} \mathrm{C}_{\text {initial }}\right)$. b. Specific ${ }^{13} \mathrm{C}$-content of heptacosane $617 \quad\left(\Gamma^{13} \mathrm{C}=\delta^{13} \mathrm{C}_{\text {heptacosane }}-\delta^{13} \mathrm{C}_{\text {bulk undegraded leaves }}\right)$. 
Nguyen Tu et al. Figure 1
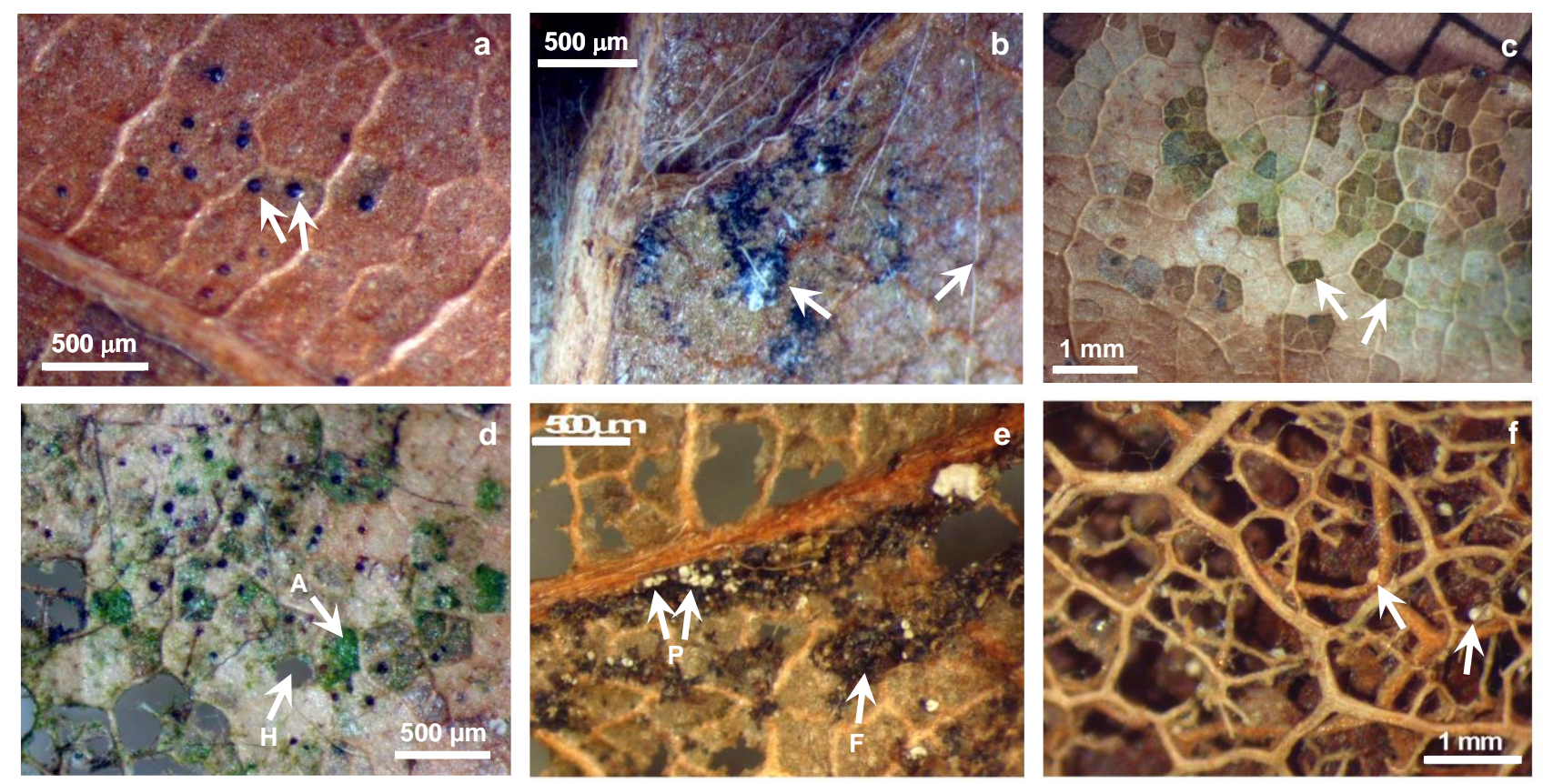

Figure 
Nguyen Tu et al. Figure 2
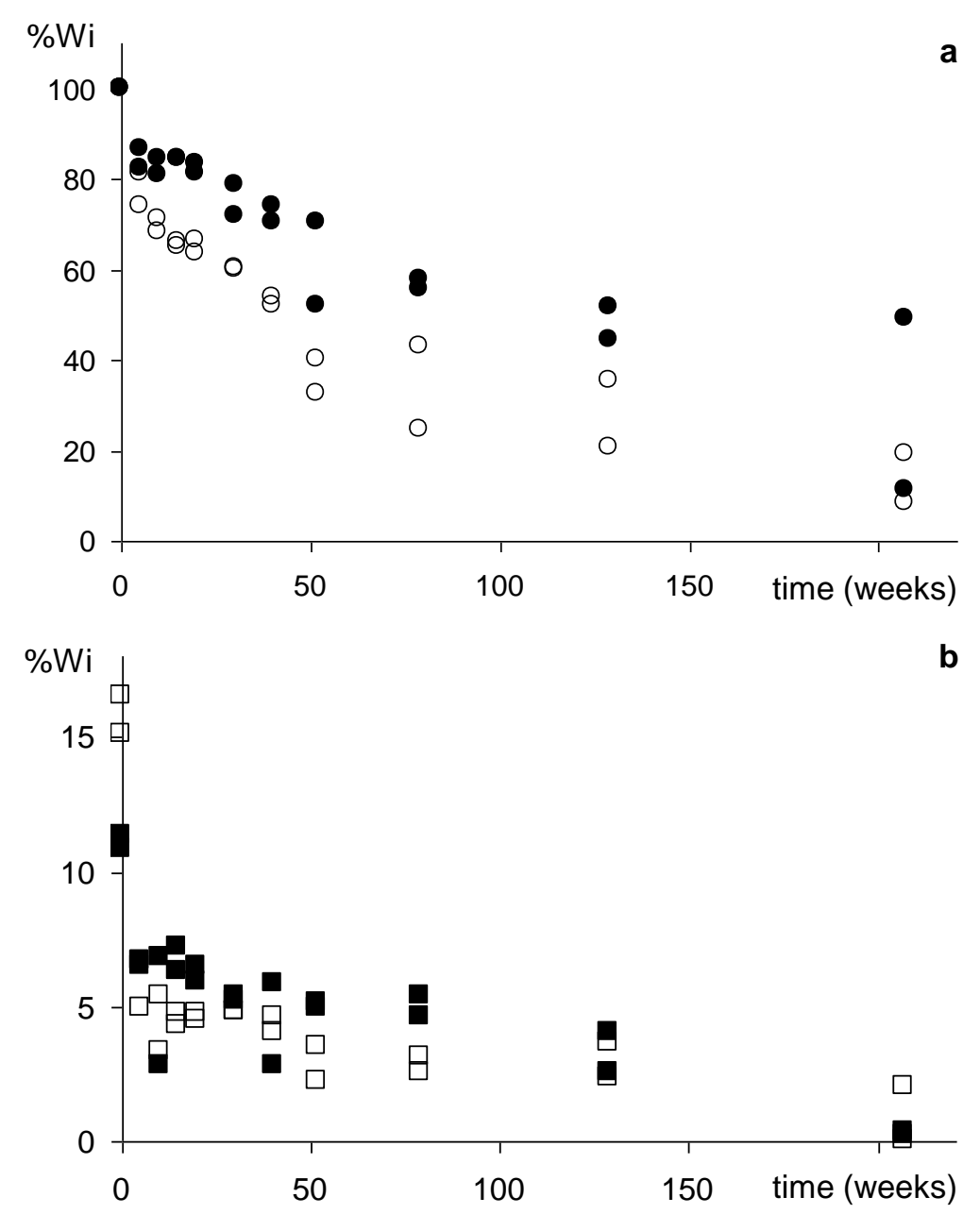

$\mu \mathrm{g} \cdot \mathrm{g}^{-1}$

c

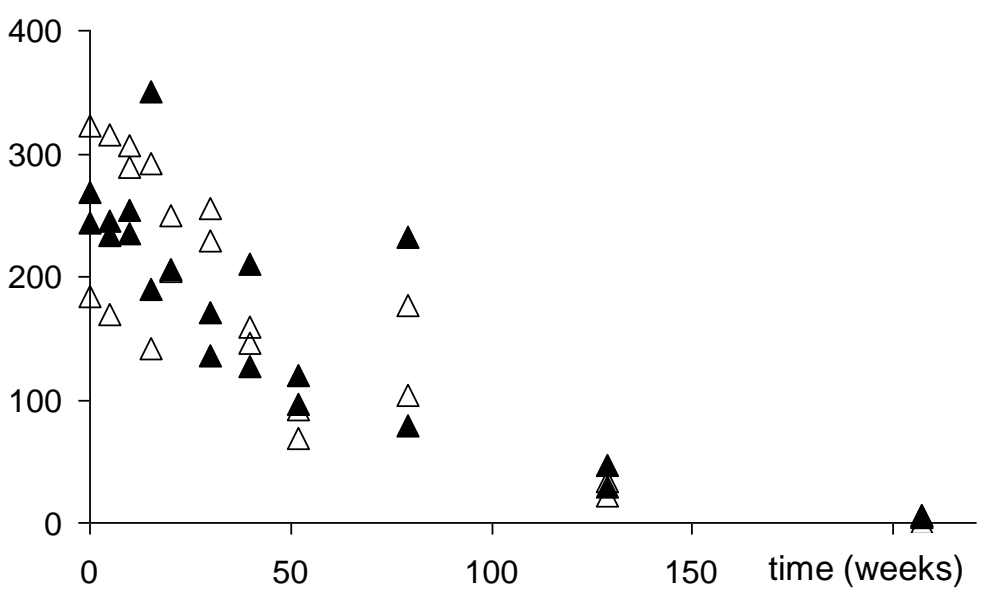


Nguyen Tu et al. Figure 3

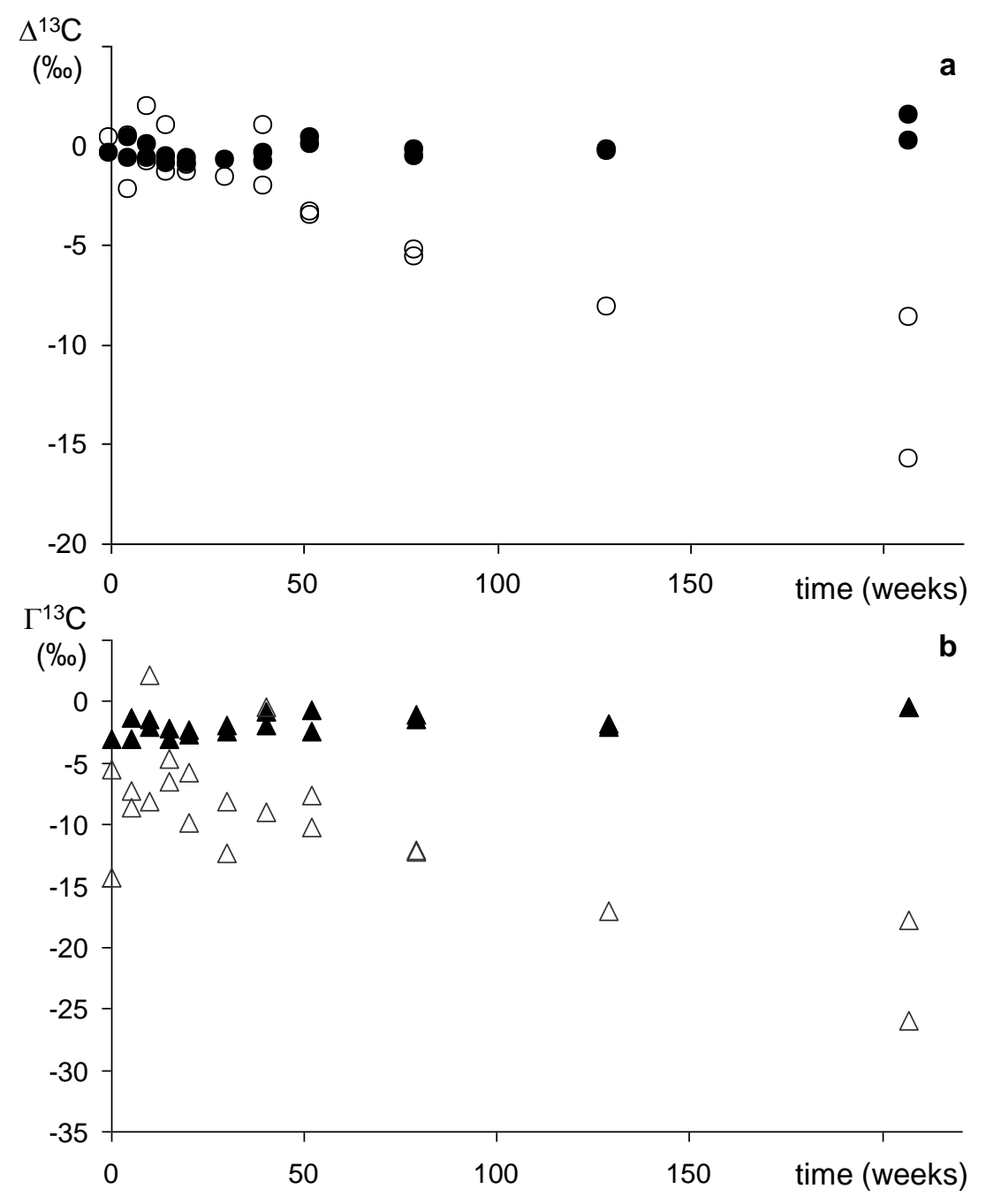


Nguyen Tu et al. Graphical abstract

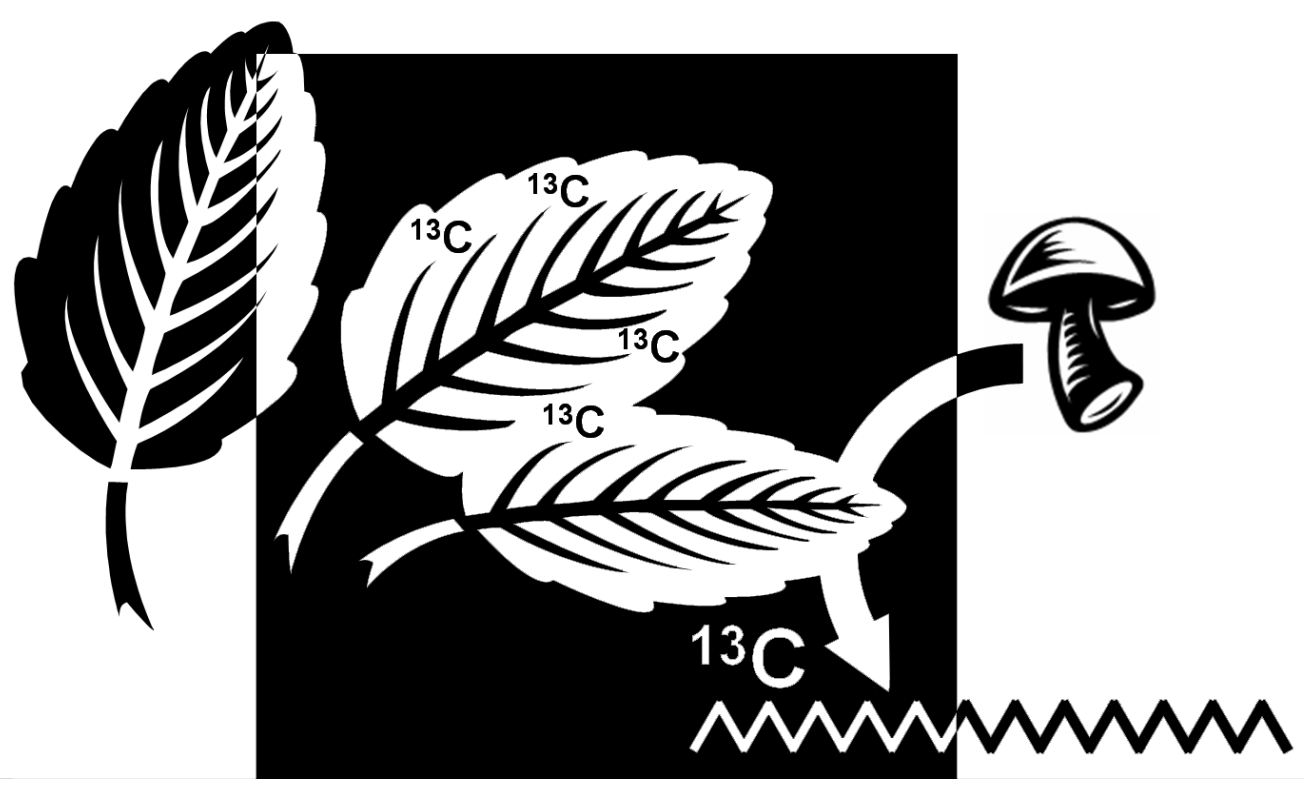

